\title{
ANALYSIS OF APPROACHES TO THE DEVELOPMENT AND VALIDATION OF THE METHODS OF ANALYSIS OF SOME ACTIVE PHARMACEUTICAL INGREDIENTS FROM THE GROUP OF ANGIOTENSIN CONVERTING ENZYME INHIBITORS IN DRUGS AND BIOLOGICAL LIQUIDS
}

\author{
LILIYA LOGOYDA* \\ Department of Pharmaceutical Chemistry, I. Horbachevsky Ternopil State Medical University, Ukraine \\ Email: logojda@tdmu.edu.ua
}

Received: 04 Apr 2019, Revised and Accepted: 17 Apr 2019

\begin{abstract}
ABSTACT
The quantity of medication brought into the marketplace is growing each year. Analytical method development is increasingly being introduced into fundamental pharmaceutical research and pharmaceutical analysis practice, taking into account their high sensitivity, accuracy, specificity and expressiveness. Search criteria was analytical method development for medicines from group of ACE inhibitors. Literature survey has been done in range of years 1990-2018 to make the review updated and comprehensive and to show the new approacheches to the development of the methods of analysis ACE inhibitors. The sources were world recognized journals and key words used as filter were angiotensin-converting enzyme inhibitors, captopril, enalapril, method development, spectrophotometry, HPLC, UHPLC. The current review is created with an intended to focus on the advantage of HPLC. Literature survey revealed that a number of methods have been reported for estimation of ACE inhibitors individually or in combination with other drugs. However, there is very few analytical methods reported for the simultaneous analysis of these drugs in a combined dosage formulation by HPLC. In additional, analysis of approaches to the development of the methods of analysis of ACE inhibitors in drugs and biological liquids has been shown that HPLC is the most suitable method for analyses ACE inhibitors in substances, drugs, biological liquids to performe routine analysis of medicines, pharmacokinetic (bioequivalence in vivo), dissolution test for final dosages forms (bioequivalence in vitro, biowaiver procedure).
\end{abstract}

Keywords: Angiotensin-converting enzyme inhibitors, Captopril, Enalapril, Spectrophotometry, HPLC, UHPLC, Pharmacokinetic, Bioequivalence

(C) 2019 The Authors. Published by Innovare Academic Sciences Pvt Ltd. This is an open access article under the CC BY license (http://creativecommons.org/licenses/by/4.0/) DOI: http://dx.doi.org/10.22159/ijap.2019v11i4.32420

\section{INTRODUCTION}

Angiotensin-converting enzyme (ACE) inhibitors help relax blood vessels. ACE inhibitors prevent an enzyme in your body from producing angiotensin II, a substance in your body that narrows your blood vessels and releases hormones that can raise your blood pressure. This narrowing can cause high blood pressure and force your heart to work harder. Many ACE inhibitors are available. Which one is best for you depends on your health and the condition being treated. People with chronic kidney disease may benefit from having an ACE inhibitor as one of their medications.

Since 1981, ACE inhibitors have been commonly prescribed to treat hypertension. This is because they tend to be well-tolerated by those who take them. They're usually taken just once a day, often in the morning. They may be prescribed along with diuretics or calcium channel blockers, which are also used to treat high blood pressure. ACE inhibitors have two primary functions. First, they decrease the amount of sodium retained in the kidneys. Secondly, they stop the production of a hormone called angiotensin II. This hormone usually causes blood vessels to narrow. When this hormone isn't produced, blood flows through the vessels more effectively. This helps the blood vessels to relax and expand, which lowers blood pressure [1]

The quantity of medication brought into the marketplace is growing each year. Physico-chemical analysis methods are increasingly being introduced into fundamental pharmaceutical research and pharmaceutical analysis practice, taking into account their high sensitivity, accuracy. Search criteria was analytical method development for medicines from group of ACE inhibitors. Literature survey has been done in range of years 1990-2018 to make the review updated and comprehensive and to show the new approacheches to the development of the methods of analysis ACE inhibitors. The sources were world recognized journals and key words used as filter were angiotensin-converting enzyme inhibitors, captopril, enalapril, method development, spectrophotometry, HPLC, UHPLC.

\section{Analytical method development of captopril}

Captopril is an angiotensin-converting enzyme (ACE) inhibitor used in the therapy of hypertension and heart failure. Captopril is associated with a low rate of transient serum aminotransferase elevations and has been linked to rare instances of acute liver injury [2]. Chemical name of captopril is (2S)-1-[(2S)-2-methyl-3sulfanylpropanoyl] pyrrolidine-2-carboxylic acid (fig. 1).

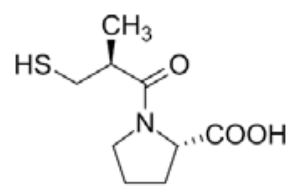

Fig. 1: The chemical structures of captopril

\begin{abstract}
The State Pharmacopoeia of Ukraine (SPhU) has the monograph on the substance of captopril and on tablets of captopril [86-94]. For identification of captopril substance, the SPhU proposes to determine the specific optical rotation and the method of absorption spectrophotometry in the infrared region, the quantitative determination-iodometry potentiometric titration using the combined platinum electrode. For identification of captopril in tablets, the SPhU proposes TLC (mobile phase-a mixture of methanol $\mathrm{P}$, ice acetic acid $\mathrm{P}$, toluene $\mathrm{P}$ (1:25:75). For quantitative determination of captopril in tablets-HPLC/UV (mobile phase-a mixture of phosphoric acid of concentrated $\mathrm{P}$, water $\mathrm{P}$ and methanol $P$ (0.5:450:550), mobile phase rate- $1.0 \mathrm{ml} / \mathrm{min}$, detection of wavelength $220 \mathrm{~nm}$ ).
\end{abstract}

The United States Pharmacopeia regulates the definition of captopril in substances, tablets and combined tablets with hydrochlorothiazide. For identification of captopril in the substance, the method of absorption spectrophotometry in the infrared region and the determination of specific optical rotation is proposed, for quantitative determination-iodatometry. For the identification of captopril in tablets, the United States Pharmacopoeia offers TLC (mobile phase-analogue to the SPhU), for quantification-HPLC/UV. According to this monograph, the following chromatographic conditions are used: chromatographic column of category L1 (with 
fixed phase C18) size $4.6 \mathrm{~mm} \times 250 \mathrm{~mm}$; mobile phase-methanol P: water P: phosphoric acid P (550:450:0.5); wavelength-220 nm, flow rate $-1.0 \mathrm{ml} / \mathrm{min}$.

The European Pharmacopoeia suggests for identification of captopril substance to determine the specific optical rotation and the method of absorption spectrophotometry in the infrared region, the quantitative determination-iodometry, potentiometric titration with the use of a combined platinum electrode.

Methods of quantitative determination of captopril in the drug and biological fluids by spectrophotometry and chromatography [3-25] methods are described in the scientific literature.

Captopril has three analytical and functional groups in its structure (carboxyl group, keto group and mercapto group), which determine the methods of captopril analysis. Titrimetric methods have not been widely used in the analysis of medical form of captopril, since the drugs have auxiliary substances that would interfere with the determination of captopril titrimetrically in medical form. Spectrophotometric methods of analysis are widely used in the analysis of drugs containing captopril. The scientific literature describes methods for determining captopril by spectrophotometry using various reagents to determine the mercapto group.

The authors S. M. El-Ashry, F. A. Ibrahim developed two spectrophotometric methods for the determination of captopril in tablets, which were based on the reactivity of thiol group. In the first method, promethazine hydrochloride during interaction with the solution of $\mathrm{N}$-Bromophthalimide in orthophosphate acid was oxidized to the free radical of promethazine, which had a maximum absorption at $516 \mathrm{~nm}$. Red color of promethazine was quantitatively reduced by captopril to colorless promethazine. Adding captopril to the red solution of promethazine resulted in reduction in absorption in direct proportion to the amount of captopril, which was the basis of spectrophotometric determination of captopril in tablets. The second method involved the use of molybdenum phosphoric acid as an oxidant to determine captopril. When captopril interacted with molybdenum phosphate acid, there was formed a reaction product of blue color during heating and the maximum of absorption was $685 \mathrm{~nm}[3,4]$.

Jovanović $\mathrm{T}$ et al. proposed spectrophotometric determination of captopril in interaction with palladium (III) chloride in the BrittonRobinson buffer solution at different $\mathrm{pH}$ values (2.14-9.10) with the formation of yellow reaction product with the maximum absorption at $380 \mathrm{~nm}$. Developed spectrophotometric method has been successfully applied for the determination of captopril in the drug [5].

Spectrophotometric method for the determination of captopril in the drug using 2,3-dichloro-1,4-naphthoquinone (dichloro) in a neutral environment with forming a product of yellow reaction with the maximum absorption at $347 \mathrm{~nm}$ is described by Dawood H. et al. [6, 7].

Scientists H. Chandru and A. C. Sharada developed a spectrophotometric method for the determination of captopril in the drug using hexacyanoferrate (III) as a reagent. Solutions of the complex have absorption maxima at $510 \mathrm{~nm}$ and are subject to the Bouguer-Lambert-Beer's law in the concentration range of 0.25 $12.00 \mu \mathrm{g} / \mathrm{ml}$. The proposed method has been successfully applied to determine this API in tablets [8].

Scientists A. Gumieniczek, D. Kowalczuk and L. Przyborowski proposed chromatographic and spectrophotometric methods of determination of captopril in tablets. The method of reverse HPLC/UV detection of captopril was developed using the chromatography column LiChrosorb RP-18 column, mobile phase-a mixture of phosphate buffer solution $\mathrm{pH} 2.4$ and acetonitrile (7:3, $\mathrm{v} / \mathrm{v}$ ) at wavelength of $211 \mathrm{~nm}$ and internal standard-celiprolol. The spectrophotometric method was based on the interaction of captopril with tetrazolium blue with the formation of a product of blue reaction having a maximum absorption at $526 \mathrm{~nm}$ [9-14].

Jebaslinhepzybai B. et al. developed HPLC/UV method for captopril determination in tablets using the chromatography column LC1 (C18) column $(250 \times 4.6 \mathrm{~mm} ; 5 \mu \mathrm{m})$ and mobile phase-a mixture of methanol and water $(55: 45 \mathrm{v} / \mathrm{v})$, flow rate- $1 \mathrm{ml} / \mathrm{min}$, detection wavelength-220 $\mathrm{nm}$. The method was linear in the range of concentrations of $80-120 \mu \mathrm{g} / \mathrm{ml}$, the correlation coefficient was 0.999. The developed method has been successfully applied for routine analysis of captopril in drugs [15].

Scientists Leanpolchareanchai J. and Suksiriworapong J. described the HPLC/UV method for the determination of captopril in extemporaneous medical form for use in pediatrics. In solution, captopril is oxidized to captopril disulfide, therefore the developed method involves the simultaneous determination of captopril and captopril disulfide in medical form. Chromatography was carried out using the mobile phase-a mixture of methanol and $0.1 \%$ phosphoric acid. Captopril holding time was 5.1-5.4 min and captopril disulphide-12.2-12.9 min. The method was linear in the concentration range $0.75-20 \mu \mathrm{g} / \mathrm{ml}$, the correlation coefficient was 0.9995. The developed method was fully validated [16].

Reverse-phase HPLC/UV method for the simultaneous determination of captopril with antagonists of $\mathrm{H}-2$ histamine receptors (cimetidine, ranitidine, famotidine) was described by Sultan N. et al. The proposed method uses the chromatography column Purospher star C18 (5 $\mu \mathrm{m}, 250 \mathrm{~mm} 4.6 \mathrm{~mm}$ ) and mobile phase-a mixture of methanol, water and phosphate buffer solution pH $3.0(60: 40 \mathrm{v} / \mathrm{v})$, mobile phase rate $-0.8 \mathrm{ml} / \mathrm{min}$, detection wavelength is $225 \mathrm{~nm}$. Captopril holding time was $5.2 \mathrm{~min}$. The method was linear in the range of concentrations of $9.3-150 \mu \mathrm{g} / \mathrm{ml}$, correlation coefficient was $0.9993, \mathrm{LOD}-1.75 \mathrm{ng} / \mathrm{ml}, \mathrm{LOQ}-5.3 \mathrm{ng} / \mathrm{ml}$. The developed method has been successfully applied to study the bioavailability of captopril in the presence of antagonists of $\mathrm{H}-2$ histamine receptors [17].

Huang T. et al. developed the reverse-phase HPLC/UV method for the simultaneous determination of captopril and hydrochlorothiazide in blood plasma using the chromatography column C(18) column (DIAMONSIL $150 \mathrm{mmx} 4 \mathrm{~mm}$ i.d., 5 microm) and mobile phase-a mixture of acetonitrile, fluoracetic acid and water in gradient elution mode, mobile phase rate $-1.2 \mathrm{ml} / \mathrm{min}$, detection wavelength is $263 \mathrm{~nm}$. Captopril holding time was $6.8 \mathrm{~min}$, hydrochlorothiazide- $16.9 \mathrm{~min}$, respectively. The method is linear in the range of concentrations of captopril 20-4000 ng/ml and hydrochlorothiazide-10-1200 ng/ml. The correlation coefficient of captopril was 0.9993, hydrochlorothiazide was 0.9999 . LOQ of captopril was $7 \mathrm{ng} / \mathrm{ml}$, of hydrochlorothiazide was $3.3 \mathrm{ng} / \mathrm{ml}$, respectively. The developed method has been successfully applied for the determination of captopril and hydrochlorothiazide in blood plasma [18].

Scientists N. Sultana, MS Arayne, S. Naveed proposed HPLC/UV method for the determination of captopril and API from the group of nonsteroidal anti-inflammatory drugs (flurbiprofen, ibuprofen, diclofenac sodium, mefenamic acid) in drugs and blood plasma using the chromatography column Purosher star C18 (250 mmx4.6 mm id, 5 microm) and mobile phase-a mixture of methanol, water, orthophosphoric acid pH $2.8(80: 20 \mathrm{v} / \mathrm{v})$, mobile phase rate-1.0 $\mathrm{ml} / \mathrm{min}$, detection wavelength-227 $\mathrm{nm}$. LOD of captopril was 1 $\mathrm{ng} / \mathrm{ml}$, whereas fluoxetine- $0.2 \mathrm{ng} / \mathrm{ml}$, ibuprofen $1 \mathrm{ng} / \mathrm{ml}$, diclofenac sodium $2 \mathrm{ng} / \mathrm{ml}$, mefenamic acid $0.4 \mathrm{ng} / \mathrm{ml}$. LOQ of captopril was 3.5 $\mathrm{ng} / \mathrm{ml}$, fluoropropene- $0.9 \mathrm{ng} / \mathrm{ml}$, ibuprofen-2.9 ng/ml, diclofenac sodium-8 $\mathrm{ng} / \mathrm{ml}$, mefenamic acid $-1 \mathrm{ng} / \mathrm{ml}$, respectively. The retention time of all analyzes was less than $12 \mathrm{~min}$ [19].

Scientists N. Aykin, R. Neal, M. Yusof, N. Ercal developed the method for the determination of captopril in biological fluids with ThioGlo 3 derivatization due to the presence of thiol group. Captopril was derivatized by ThioGlo 3 [3H-naphtho [2,1-b]pyran,9-acetoxy-2-(4(2,5-dihydro-2,5-dioxo-1H-pyrrol-1yl)phenyl-3-oxo-)].

Chromatography was performed using the chromatography column Astec C (18) column and mobile phase-a mixture of water, acetonitrile, acetic acid, phosphoric acid (50:50, $1 \mathrm{ml} / \mathrm{l}$ of acids) per wavelength of excitation of $365 \mathrm{~nm}$ and wavelength of radiation of $445 \mathrm{~nm}$. The developed method was used to determine captopril in biological fluids [20,21].

Li K. et al. described HPLC/UV method for the determination of captopril in blood plasma and the use of this method for the study of pharmacokinetics. The proposed method uses the chromatography column Spherisorb C18 column and mobile phase-a mixture of 
water, acetonitrile, acetic acid (44:55:0.2, v/v/v), internal standard4-chloro-2-nitroaniline, detection wavelength-258 nm. Captopril holding time was $5.2 \mathrm{~min}$. The method was linear in the range of 5$500 \mathrm{ng} / \mathrm{ml}$, LOD-2 ng/ml, Tmax-0.56 h, Cmax-266.5 ng/ml, AUC (zero)-infinity-380.3 ng/ml. The developed method was successfully applied for the study of pharmacokinetics [22-24].

Scientists Papanov S., Hadjieva B., N. Koleva developed the reversephase HPLC/UV method for the determination of captopril in tablets using the chromatography column LiChrosorb ${ }^{\circledR}$ RP-18 $(10 \mu \mathrm{m}$, $250 \times 4 \mathrm{~mm}$ ) and mobile phase-a mixture of methanol and water $(60: 40 \% \mathrm{v} / \mathrm{v})$ with the addition of phosphatic acid to $\mathrm{pH} 3.0$, mobile phase rate- $2.0 \mathrm{ml} / \mathrm{min}$, column temperature- $30{ }^{\circ} \mathrm{C}$, detection wavelength-220 nm. Captopril holding time was $8 \mathrm{~min}$. The method is linear in the range of concentrations of captopril $25-200 \mu \mathrm{g} / \mathrm{ml}$, correlation coefficient-0.9997. LOD of captopril was $7 \mathrm{ng} / \mathrm{ml}, \mathrm{LOQ}-$ $20 \mathrm{ng} / \mathrm{ml}$, respectively. The developed method was successfully applied for the determination of captopril in drugs [25-47].

A simple, rapid, sensitive, and specific method was developed for the determination of captopril by UHPLC in mono-medicines and pharmaceutical dosage forms in combination with hydrochlorothiazide without previous separation. Satisfactory resolution was achieved using Fused-Core ${ }^{\circledR}$ technology Ascentis Express C18 column $(4.6 \times 150 \mathrm{~mm})$ and a mobile phase consisting of methanol and $0.1 \%$ solution of trifluoroacetic acid $(40 / 60, v / v)$ at a flow rate $1.2 \mathrm{ml} /$ minute and the wavelength detection was $220 \mathrm{~nm}$. Ascentis Express columns, based on Fused-core particle technology, provide more than twice the speed and efficiency of traditional columns at half the backpressure of sub-2- $\mu \mathrm{m}$ columns. Compared to the previous method [18], the retention time for captopril was 1.345 min [28]. The shorter run-time of UHPLC methods results in reducing organic solvent volumes and the whole time of analysis, without decreasing the sensitivity and resolution of determination. Moreover, laboratory staff are less exposed to toxic agents and solvolysis of analytes caused by the presence of organic solvents is limited. Taking into consideration the above mentioned advantages UHPLC methods may be recommended for studies adopting a green approaches to pharmaceutical analysis of ACE inhibitors.

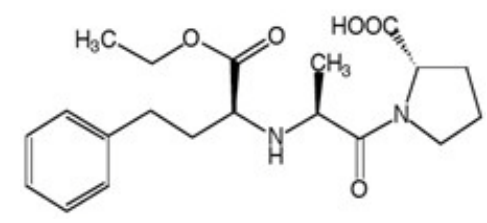

Fig. 2: The chemical structures of enalapril

\section{Analytical method development of enalapril}

Enalapril is an angiotensin-converting enzyme (ACE) inhibitor widely used in the therapy of hypertension and heart failure. Enalapril is associated with a low rate of transient serum aminotransferase elevations and has been linked to rare instances of acute liver injury [2]. Chemical name of enapalril is (2S)-1-[(2S)-2[[(1S)-1-ethoxy-1-oxo-4-phenylbutan-2-yl]amino]propanoyl] pyrolidine-2-carboxylic acid (fig. 2).

The State Pharmacopoeia of Ukraine (SPhU) has the monograph on the substance of enalapril maleate and on enalapril tablets. For identification of the substance of enalapril maleate, the SPhU offers the method of absorption spectrophotometry in the infrared region, quantitative determination-alkalimetry potentiometric titration. For identification of enalapril in tablets, the SPhU proposes TLC (mobile phase-a mixture of acetic acid of ice $\mathrm{P}$, water $\mathrm{P}$, butanol $\mathrm{P}$ (15:25:60). For the quantitative determination of enalapril in tablets-HPLC/UV (mobile phase-a mixture of acetonitrile $\mathrm{P}$ and solvent (40:60), solvent-potassium dihydrogen phosphate solution $\mathrm{P}$, mobile phase rate- $1.0 \mathrm{ml} / \mathrm{min}$, detecting by wavelength at $215 \mathrm{~nm}$ ).

The United States Pharmacopeia regulates the determination of enalapril maleate in substances and tablets. For the identification of enalapril maleate in the substance, the method of absorption spectrophotometry in the infrared region and HPLC/UV, for the quantitative determination-HPLC/UV is proposed. For the identification and quantification of enalapril in tablets, the United States Pharmacopeia offers HPLC/UV. According to this monograph, the following chromatographic conditions are used: chromatographic column of category L1 (fixed phase C18) with size $4.6 \mathrm{~mm} \times 250 \mathrm{~mm}$; mobile phase-a mixture of buffer solution (solution of sodium dihydrogen phosphate with the addition of phosphoric acid to $\mathrm{pH} 2.2$ ): acetonitrile $\mathrm{P}$ (75:25); wavelength-215 $\mathrm{nm}$, flow rate $-2.0 \mathrm{ml} / \mathrm{min}$.

The European Pharmacopeia [3] suggests the method of absorbing spectrophotometry in the infrared region for the identification of substance enalapril maleate, quantitative determination-alkalimetry potentiometric titration.

Methods of quantitative determination of enalapril maleate in drugs and biological fluids by methods of spectrophotometry and chromatography [48-75] are described in the scientific literature.

Scientists Dubey S. K., Kumar S., Mudakavi R. J., Deshpande S. developed the UV-spectrophotometric method of enalapril maleate determination. The maximum absorption of enalapril-207 $\mathrm{nm}$. The method was linear in the range of concentrations of $2-28 \mu \mathrm{g} / \mathrm{ml}$ and phosphate buffer solution $\mathrm{pH}$ 7.2. The developed method can be used in routine analysis of drugs containing enalapril maleate [48].

Ayad M. M. et al. described methods of spectrophotometric determination of enalapril and ramipril by formation of complexes. The complex compound (enalapril, eosin, cuprom (II)) was determined in two ways. The first method is the extraction of the complex compound with chloroform and determination of the optical substance at $533.3 \mathrm{~nm}$. Subjection to the Bouguer-LambertBeer's law in the concentration range-56-112 $\mu \mathrm{g} / \mathrm{ml}$. The second method is direct measurement of the optical density at $558.8 \mathrm{~nm}$ after the addition of methyl cellulose at $\mathrm{pH}$ 5. Subjection to the Bouguer-Lambert-Beer's law in the concentration range-19-32 $\mu \mathrm{g} / \mathrm{ml}$. The proposed methods were successfully applied to determine enalapril and ramipril in medical form [49].

Baraka M. M. et al. proposed spectrophotometric methods for the determination of ramipril, enalapril, and fosinopril drugs, which were based on the formation of complex compounds in the interaction with molybdenum (V) thiocyanate, which was extracted with chloroform. The solutions of complex have absorption maxima at $517 \mathrm{~nm}$ and are subject to the Bouguer-Lambert-Beer's law in the range of enalapril concentrations of $4-36 \mu \mathrm{g} / \mathrm{ml}$, ramipril and fosinopril-10-90 $\mu \mathrm{g} / \mathrm{ml}$. Another way was direct determination of the complex compound after adding benzalkonium chloride as surfactant. Solutions of complex have absorption maxima at $545 \mathrm{~nm}$ and are subject to the Bouguer-Lambert-Beer's law in the range of enalapril concentrations of 3-27 $\mu \mathrm{g} / \mathrm{ml}$, ramipril and fosinopril-8-72 $\mu \mathrm{g} / \mathrm{ml}$. The developed methods were successfully applied for the determination of ramipril, enalapril, and fosinopril in drugs [50].

Scientists Ayad M. M., Shalaby A., Abdellatef H. E., Hosny M. M. developed spectrophotometric methods for determination of enalapril and timolol in drugs. The first method was based on the formation of a complex compound with palladium (II) chloride in buffer media, while the second method was the formation of colored complexes in interaction with palladium (II) salt, eosin and detectable APIs using methylcellulose as surfactant to increase the solubility of complex compounds. Solutions of complex have absorption maxima at 369.4 $\mathrm{nm}$ of timolol and $362.8 \mathrm{~nm}$-enalapril and are subject to the BouguerLambert-Beer's law in the range of concentrations of timolol 20-200 $\mu \mathrm{g} / \mathrm{ml}$ and enalapril $50-300 \mu \mathrm{g} / \mathrm{ml}$ for the first method. The second method was more sensitive and the Bouguer-Lambert-Beer's law was in the range of timolol concentrations $1.6-16 \mu \mathrm{g} / \mathrm{ml}$ and enalapril-8-56 $\mu \mathrm{g} / \mathrm{ml}$, respectively. The developed spectrophotometric methods were successfully applied for the determination of timolol and enalapril in drugs [51,52].

Sowjanya G. et al. described the spectrophotometric method of enalapril and hydrochlorothiazide determination in tablets. The maximum absorption of enalapril was observed in a deep ultraviolet with wavelength of $207 \mathrm{~nm}$, and hydrochlorothiazide-272 nm. The 
method was linear in the range of concentrations of enalapril 5-50 $\mu \mathrm{g} / \mathrm{ml}$ and hydrochlorothiazide- $-5-30 \mu \mathrm{g} / \mathrm{ml}$, respectively $[53,54]$.

Scientists Rahman N., Manirul Haque S. K. developed spectrophotometric methods for determination of enalapril maleate in drugs. The first method was based on the interaction of enalapril with potassium iodate and potassium iodide to form a yellow reaction product with a maximum absorption at $352 \mathrm{~nm}$. Other methods were based on the reaction of complexation with $n$ chloranalic acid in environment of 1,4-dioxane methanol, from 2,2dichloro-5,6-dicyano-1,4-benzoquinone in environment of acetonitrile-1,4 dioxane, with potassium iodide in environment acetonitrile-dichloromethane. Subjection to the Bouguer-LambertBeer's law was in the range of concentrations of 2.5-50, 20-560, 5-75 and $10-200 \mu \mathrm{g} / \mathrm{ml}$, respectively. The developed methods were successfully applied for the spectrophotometric determination of enalapril maleate in drugs [55].

Simona Gherman et al. offered the spectrophotometric method of determination of enalapril maleate in drugs of different manufacturers. The method was based on the dissolution of enalapril in buffer solution of $\mathrm{pH} 4$, the maximum absorption was observed at $208 \mathrm{~nm}$. The method was linear in the range of concentrations of 1-20 $\mu \mathrm{g} / \mathrm{ml}, \mathrm{LOD}-0.3721 \mu \mathrm{g} / \mathrm{ml}, \mathrm{LOQ}-0.9019 \mu \mathrm{g} / \mathrm{ml}[56]$.

Scientists Manindra M., Zafar H. S. and Ankur K. described HPLC/UV method for the determination of enalapril maleate in tablets using the chromatography column Hypersil MOS, $5 \mu(250 \mathrm{~mm} \times 4.6 \mathrm{~mm}$ ) and mobile phase-a mixture of buffer solution and acetonitrile (40:60, v/v), flow rate $-1.5 \mathrm{ml} / \mathrm{min}$, wavelength detection-215 nm. Enalapril holding time was $9.72 \mathrm{~min}$. The method was linear in the range of concentrations of $150-250 \mu \mathrm{g} / \mathrm{ml}$, correlation coefficient was 0.9992 . The developed method was successfully applied for the control of the quality of drugs that contain enalapril maleate [57].

Scientists Al-Momani F. developed the HPLC/UV method for determination of enalapril maleate and hydrochlorothiazide in tablets using the chromatography column Supelcosil LC-8 $(5 \mu \mathrm{m}, 150 \mathrm{~mm} \times 4.6$ $\mathrm{mm}$ i.d.), internal standard-theophylline and mobile phasetetrabutylammonium hydrogen sulfate in acetonitrile, water, tetraamine (14:85.6:6.4, v/v/v) with addition of ice acetic acid to $\mathrm{pH}$ 4.1 , detection wavelength-220 $\mathrm{nm}$. The developed method was used to determine enalapril maleate and hydrochlorothiazide in drugs [58].

Reverse-phase HPLC/UV method for the simultaneous determination of enalapril maleate and hydrochlorothiazide in drugs was proposed by Suryadevara Vidyadhara et al. The developed method uses the chromatography column C18 column (ODS UG column $250 \mathrm{~mm} \times 4.5 \mathrm{~mm}$ ) and mobile phase-a mixture of acetate buffer, methanol and acetonitrile (60:20:20 V/V/V, pH 5), mobile phase rate- $0.8 \mathrm{ml} / \mathrm{min}$, detection wavelength-232 nm. Enalapril maleate holding time was $2.8 \mathrm{~min}$, hydrochlorothiazide $-4.1 \mathrm{~min}$. The method was linear in the range of concentrations of $10-30 \mu \mathrm{g} / \mathrm{ml}$, correlation coefficient was 0.999 , LOD enalapril-0.16 $\mu \mathrm{g} / \mathrm{ml}$, LOQ enalapril- $0.49 \mu \mathrm{g} / \mathrm{ml}$. The developed method was successfully applied for the determination of enalapril maleate and hydrochlorothiazide in drugs [59].

The scientist Bharat G. described the HPLC/UV method for determining enalapril maleate and amlodipine in drugs using the chromatography column Phenomenex C18 (5 $\mu \mathrm{m}, 250 \mathrm{~mm} 4.6$

$\mathrm{mm}$ ) and mobile phase-a mixture of methanol, acetonitrile, water $(40: 50: 10, \mathrm{v} / \mathrm{v} / \mathrm{v})$, mobile phase rate- $1.0 \mathrm{ml} / \mathrm{min}$. Enalapril holding time was $2.27 \mathrm{~min}$, amlodipine was $5.07 \mathrm{~min}$. The method was linear in the enalapril concentration range of $0.5-6.0 \mu \mathrm{g} / \mathrm{ml}$, correlation coefficient was 0.9989 , LOD of enalapril- $0.04 \mu \mathrm{g} / \mathrm{ml}$, LOQ of enalapril- $0.4 \mu \mathrm{g} / \mathrm{ml}$. The method was linear in the amlodipine concentration range of $0.5-8.0 \mu \mathrm{g} / \mathrm{ml}$, correlation coefficient was 0.9983 , LOD of amlodipine was $0.04 \mu \mathrm{g} / \mathrm{ml}, \mathrm{LOQ}-0.4 \mu \mathrm{g} / \mathrm{ml}$. The developed method was successfully applied for the determination of enalapril maleate and amlodipine in drugs [60].

Scientists Sultana N., Saeed A. and Naveed S. developed the method of reverse-phase HPLC/UV determination of enalapril maleate in the presence of API from the group of statins (rosuvastatin, atorvastatin, simvastatin). Chromatography was performed using the chromatographic column Purospher Star, C18 ( $5 \mathrm{~mm}, 250$ x $4.6 \mathrm{~mm}$ ) and mobile phase-a mixture of acetonitrile and water $(60: 40 \mathrm{v} / \mathrm{v})$, detection wavelength- $230 \mathrm{~nm}$. The holding time of all analytes was less than $10 \mathrm{~min}$. The method was linear in enalapril concentration range of $2.5-100.0 \mu \mathrm{g} / \mathrm{ml}$, correlation coefficient-0.9995 whereas the method was linear in the range of concentrations of API 0.625$25.0 \mu \mathrm{g} / \mathrm{ml}$ of statins group, correlation coefficient was 0.9990 . LOD of enalapril was $3.9 \mathrm{ng} / \mathrm{ml}$, while rosuvastatin was $0.03 \mathrm{ng} / \mathrm{ml}$, atorvastatin $0.04 \mathrm{ng} / \mathrm{ml}$, simvastatin was $0.02 \mathrm{ng} / \mathrm{ml}$. LOQ was 12 $\mathrm{ng} / \mathrm{ml}$, while rosuvastatin $-0.09 \mathrm{ng} / \mathrm{ml}$, atorvastatin $-0.1 \mathrm{ng} / \mathrm{ml}$, simvastatin $-0.07 \mathrm{ng} / \mathrm{ml}$. The developed method was successfully applied for the determination of enalapril maleate in the presence of API from the group of statins $[61,62]$.

Nagarajan G. et al. proposed the HPLC/UV method for determination of enalapril and ramipril in drugs using the chromatographic column

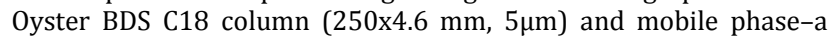
mixture of buffer solution A (aqueous solution of sodium perchloride with the addition of triethylamine, with phosphoric acid $\mathrm{pH} 3.6 \pm 0.1$ and addition of acetonitrile) and buffer solution B (aqueous sodium perchloride solution with addition of triethylamine, formation of phosphoric acid $\mathrm{pH}$ of $2.6 \pm 0.1$ and addition of acetonitrile) $(50: 50, \mathrm{v} / \mathrm{v})$, mobile phase rate $-1.0 \mathrm{ml} / \mathrm{min}$, detection wavelength-208 $\mathrm{nm}$. Enalapril holding time was 4.197 min, ramiprilum-5.819 min. The method was linear in the range of concentrations of $5-30 \mu \mathrm{g} / \mathrm{ml}$ of both analytes, limits of enalapril and ramipril detection $-0.571 \mu \mathrm{g} / \mathrm{ml}$ and $1.090 \mu \mathrm{g} / \mathrm{ml}$, respectively, the limit of enalapril and ramipril detection $-1.733 \mu \mathrm{g} / \mathrm{ml}$ and 3.303 $\mu \mathrm{g} / \mathrm{ml}$, respectively. The developed method was successfully applied for routine analysis of enalapril and ramipril in drugs [63].

Scientists Walily A. M., Belal S. F., Heaba E. A., Kersh A. E. described the determination of enalapril maleate and hydrochlorothiazide by UV spectrophotometry and HPLC/UV methods (mobile phase-a mixture of acetonitrile and water $(20: 80, v / v)$, detection wavelength-215 $\mathrm{nm}$ for enalapril and $275 \mathrm{~nm}$ for hydrochlorothiazide) [64].

Scientists Tajerzadeh $H$. and Hamidi M. developed HPLC/UV methods for enalaprilatum determination. The method was linear in the range of concentrations of $1-200 \mu \mathrm{g} / \mathrm{ml}$, LOD of enalaprilatum$0.125 \mu \mathrm{g} / \mathrm{ml}$, LOQ of enalaprilatum- $0.5 \mu \mathrm{g} / \mathrm{ml}$. The developed method makes it possible to clearly separate the peaks of enalaprilatum and enalapril, so it can be used to determine enalapril in the presence of enalaprilatum [65].

Scientists Uslu B. and Ozden T. proposed HPLC/UV and UHPLC/UV methods for enalapril and hydrochlorothiazide determination in drugs using chromatographic columns Waters $\mu$-Bondapak C 18 $(300 \times 3.9 \mathrm{~mm}, 10 \mu \mathrm{m})$ and Waters Acquity BEH C18 $(100 \times 2.1 \mathrm{~mm}$, $1.7 \mu \mathrm{m})$. Enalapril holding time by HPLC/UV method was $5.3 \mathrm{~min}$, while by UHPLC/UV method was 1.95 min. The HPLC/UV method was linear in the range of enalapril concentrations of $0.270-399$ $\mu \mathrm{g} / \mathrm{ml}$ and hydrochlorothiazide $0.260-399 \mu \mathrm{g} / \mathrm{ml}$. The UHPLC/UV method was linear in the range of concentrations of enalapril 0.270$399 \mu \mathrm{g} / \mathrm{ml}$ and hydrochlorothiazide $0.065-249 \mu \mathrm{g} / \mathrm{ml}$. The developed method was successfully applied for the determination of enalapril and hydrochlorothiazide in drugs. It can also be used as an example of increasing the expressiveness of methods for the determination of various APIs [66].

Scientists Hossein Danafar and Mehrdad Hamidi described the bioanalytical method for enalapril and enalaprilatum in blood plasma by the HPLC/MS method using the chromatographic column C (18) column and mobile phase-a mixture of methanol, water, formic acid $(74: 24: 2 \mathrm{v} / \mathrm{v} / \mathrm{v})$, mobile phase rate- $0.2 \mathrm{ml} / \mathrm{min}$. Total chromatography time was $1.25 \mathrm{~min}$. The method is linear in the range of concentrations of $0.1-20 \mathrm{ng} / \mathrm{ml}$ of both analytes, the correlation coefficient was more than 0.999 . LOD was $0.08 \mathrm{ng} / \mathrm{ml}$, LOQ was $0.1 \mathrm{ng} / \mathrm{ml}$, respectively. The developed method was successfully applied for the determination of enalapril and enalaprilatum in blood plasma [67-71].

Qi Gu et al. developed the HPLC/MS method for enalapril and enalaprilatum detection in blood plasma using the chromatographic column Zorbax Extend-C (18). Total chromatography time was 3.5 
min. The method was linear in the range of concentrations of 0.1$100.0 \mathrm{ng} / \mathrm{ml}$ for both analytes, LOQ- $0.1 \mathrm{ng} / \mathrm{ml}$, respectively. The developed method was successfully applied for the determination of enalapril and enalaprilatum in blood plasma and conducting of pharmacokinetic studies [72, 73].

Scientists Niopas I., Daftsios A. C., Nikolaidis N. described the bioanalytical method of enalapril determination using the developed method for study the bioequivalence of two tablet drugs with enalapril (Antiprex (Elpen, Greece) and Renitec (Vianex, Greece)) [74].

Siddiqui F. A. et al. proposed the HPLC/UV method for the determination of metformin in the presence of ACE inhibitors (captopril, lisinopril, enalapril) in drugs and the use of developed method for the study of pharmacokinetics. Chromatography was performed using the chromatography column Purospher ${ }^{\circledR}$ StarRP18 endcapped ( $250 \mathrm{~mm} \times 4.6 \mathrm{~mm}$ id) and mobile phase-a mixture of methanol and water $(50: 50 \mathrm{v} / \mathrm{v})$ with the addition of phosphate acid to produce $\mathrm{pH} 3.1$, mobile phase rate $-1.0 \mathrm{ml} / \mathrm{min}$, and detection wavelength-208 $\mathrm{nm}$. The method was linear in the range of concentrations of metformin $10-10000 \mathrm{ng} / \mathrm{ml}$ and $30-10000 \mathrm{ng} / \mathrm{ml}$ API from the ACE inhibitors group, correlation coefficient- 0.9964 . The developed method was successfully applied to study the pharmacokinetics of metformin, captopril, lisinopril and enalapril [75].

Among the disadvantages of spectrophotometry, low selectivity, low sensitivity and relatively high variability of the results of the analysis can be noted. The current review is created with an intended to focus on the advantage of HPLC for determination of ACE inhibitors. In the design of HPLC and UHPLC techniques, it is necessary to consider many factors that will influence the results of the analysis, namely the size of the chromatographic column, the type of the stationary phase and the size of its particles, the temperature of the column, the composition of the mobile phase and the rate of its feed, the method of detection, conditions of sample preparation of solutions and others The choice of the column type is made taking into account the physical and chemical properties of the analyzed analytes. Development of chromatographoc conditions for HPLC and UHPLC under analytical method development presents on fig. 3.

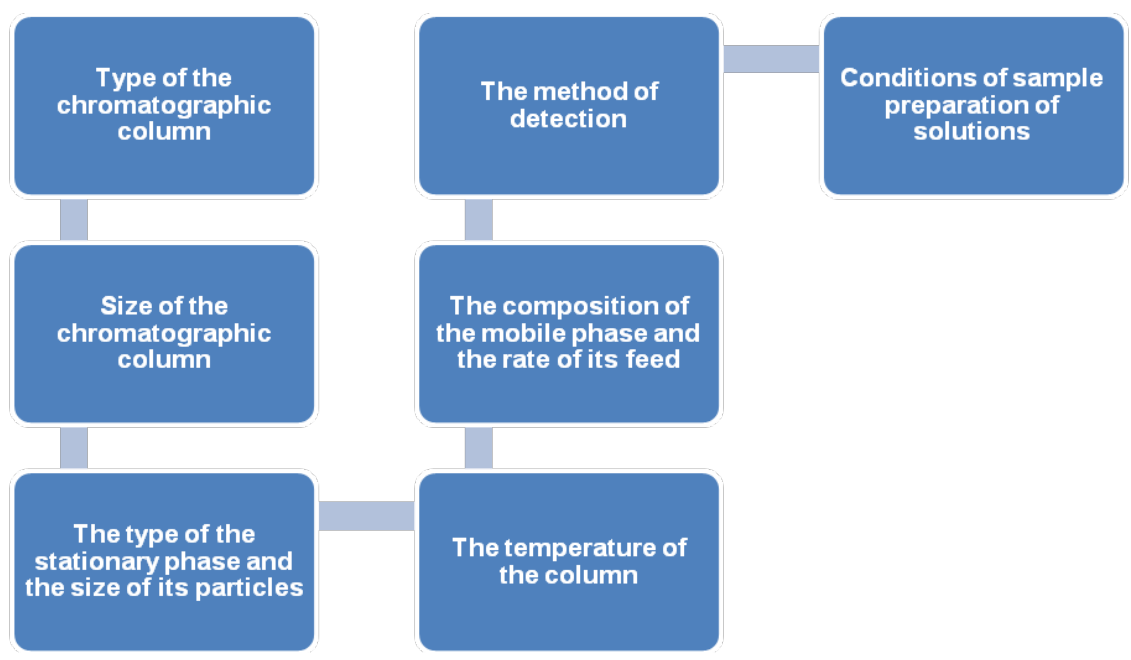

Fig. 3: Development of chromatographoc conditions for HPLC (UHPLC)

\begin{abstract}
Literature survey revealed that a number of methods have been reported for estimation of ACE inhibitors individually or in combination with other drugs. However, there is very few analytical methods reported for the simultaneous analysis of these drugs in a combined dosage formulation by HPLC. In additional, analysis of approaches to the development of the methods of analysis of ACE inhibitors in drugs and biological liquids has been shown that HPLC is the most suitable method for analyses ACE inhibitors in substances, drugs, biological liquids to performe routine analysis of medicines, pharmacokinetic (bioequivalence in vivo), dissolution test for final dosages forms (bioequivalence in vitro, biowaiver procedure).
\end{abstract}

\section{CONCLUSION}

In light of the benefits discussed in this review, we can conclude that analysts are constantly working on developing new methods of analysis of ACE inhibitors in drugs and biological liquids and on their optimization in order to save time and consumables, which also ensures the efficiency of the developed methodology. Among the disadvantages of spectrophotometry, low selectivity, low sensitivity and relatively high variability of the results of the analysis can be noted. Therefore, the advantage is provided by HPLC. Literature survey revealed that a number of methods have been reported for estimation of ACE inhibitors individually or in combination with other drugs. However, there is very few analytical methods reported for the simultaneous analysis of these drugs in a combined dosage formulation by HPLC. The way of solving the outlined problem lies in the plan of creating unified approaches to the development and validation of analytical methods of determination, taking into account their features, goals and objectives.

\section{AUTHORS CONTRIBUTIONS}

All the author have contributed equally

\section{CONFLICT OF INTERESTS}

\section{Declared none}

\section{REFERENCES}

1. https://www.mayoclinic.org/diseases-conditions/high-bloodpressure/in-depth/ace-inhibitors/art-20047480 [Last accessed on 01 Jan 2019]

2. https://pubchem.ncbi.nlm.nih.gov/compound/44093\#section =Drug-and-Medication-Information [Last accessed on 01 Jan 2019].

3. El-Ashry SM, Ibrahim FA. Colorimetric determination of captopril in dosage forms. Anal Lett 1992;25:1657-72.

4. Ashour FM, Salama FM, Aziza MAE. A colorimetric method for the determination of captopril. J Drugs Res 1990;19:323-6,

5. Jovanivic T, Stanovic B, Koricanac Z. Spectrophotometric investigation on complex-formation of captopril with palladium (II) and its analytical application. J Pharm Biomed Anal 1995;13:213-7.

6. Dawood HM, Intesar AS, Hend A. Spectrophotometric method for the determination of captopril in pharmaceutical formulations. Baghdad Sci J 2013;10:965-70.

7. Sanghavi NM, Samarth MM, Matharu R, Singh PS. Colorimetric estimation of captopril and its formulations. Indian Drugs 1991;28:189-91.

8. Chandru H, Sharada AC. Simple and rapid methods for the analysis of captopril in dosage forms. E J Chem 2007;4:216-21. 
9. Gumieniczek A, Kowalczuk D, Przyborowski L. The chromatographic and colorimetric methods for determination of captopril in tablets. Acta Pol Pharm 1998;55:21-4.

10. Bald E, Sypniewski S. Determination of thiol drugs in pharmaceutical formulations as their 5-pyridinium derivatives by high-performance liquid chromatography with ultraviolet detection. Fresenius J Anal Chem 1997;358:554-5.

11. Cavrini V, Gatti R, Dipreta AM, Raggi MA. Determination of thiol drugs in pharmaceutical formulations using ethacrynic-acid as a precolumn ultraviolet derivatizaon reagent. Chromatographia 1987;23:680-3.

12. Cavrini V, Gatti R, Andrisano V, Gatti R. 1,1'-[ethenylidenebis (sulfonyl)] bis-benzene: a useful pre-cromatographic derivatization reagent for HPLC analyses of thiol drugs. Chromatographia 1996;42:515-20.

13. Favaro G, Fiorani M. Determination of pharmaceutical thiols by chromatography with electrochemical detection: use of an electrode with conductive carbon cement matrix, chemically modified with cobalt phthalocyanine. Anal Chim Acta 1996;332:249-55.

14. Bald E, Sypniewski S, Drzewoski J, Stepien M. Application of 2halopyrinidium salts as ultraviolet derivatization reagents and solid-phase extraction for determination of captopril in human plasma by high performance liquid chromatography. J Chromatogr B: Biomed Appl 1996;681:283.

15. Jebaslinhepzybai B, Velmurugan C, Chenthilnathan A. Validation of the RP-HPLC method for analysis of captopril in pharmaceutical tablets. Der Pharm Sin 2016;7:1-6.

16. Leanpolchareanchai J, Suksiriworapong J. Validation of analytical method for captopril extemporaneous preparations by high performance liquid chromatography. MU J Pharm Sci 2015;42:85-92.

17. Sultan N, Naveed S, Arayne MS. RP-HPLC method for the simultaneous determination of captopril and H2-receptor antagonist: application to interaction studies. Med Chem 2013;3:183-7.

18. Huang T. Simultaneous determination of captopril and hydrochlorothiazide in human plasma by reverse-phase HPLC from linear gradient elution. J Pharma Biomed Anal 2006;41:644-8.

19. Sultana N, Arayne MS, Naveed S. Simultaneous quantitation of captopril and NSAID's in API, dosage formulations and human serum by RP-HPLC. J Chin Chem Soc 2010;57:62-7.

20. Aykin N, Neal R, Yusof M, Ercal N. Determination of captopril in biological samples by high-performance liquid chromatography with ThioGlo ${ }^{\mathrm{TM}} 3$ derivatization. Biomed Chromatogr 2001; 15:427-32.

21. Gao S, Weirong T, Shixiang W. Simple highperformance liquid chromatographic method for the determination of captopril in biological fluids. J Chromatogr B: Biomed Appl 1992;582:258-62.

22. Li K, Tan L, Zhou J. HPLC determination of captopril in human plasma and its pharmacokinetic study. Biomed Chromatogr 1996;10:237-9.

23. Ito T, Matsuki Y, Kurihara H, Nambara T. Sensitive method for determination of captopril in biological fluids by gas chromatography-mass spectrometry. J Chromatogr 1987; 417:79-87.

24. Y Matsuki. Determination of captopril in biological fluids by gas-liquid chromatography. J Chromatogr 1993;188:177-83.

25. Papanov S, Hadjieva B, Koleva N. Rapid RP-HPLC method for estimation of captopril from tablet dosage form. Int J Biol Pharm Allied Sci 2014;3:317-25.

26. Yuliya Kondratova, Liliya Logoyda, Yuliia Voloshko, Ahmed Abdel Megied, Dmytro Korobko, Yuriy Soroka. Development and validation of HPLC-DAD method for the determination of bisoprolol in tablet dosage forms. Int J Appl Pharma 2017;9:54-9.

27. Kondratova Y, Adebayo T, Logoyda L, Korobko D, Berdey I, Kuchmerovska T. Development of the methodology of the chromatographic determination of amlodipine in medicines. Int J Res Ayurveda Pharm 2016;7:32-5.

28. Liliya Logoyda, Yuliya Kondratova, Dmytro Korobko, Yuriy Soroka. Development of UHPLC method for the determination of captopril in pharmaceutical dosage forms. Asian J Pharm Clin Res 2017;10:308-10.
29. Liliya Logoyda, Ahmed M Abdel-Megied, Yuliya Kondratova, Olena Trofimenko, Dmytro Korobko, Iryna Dakhym. Development and validation of HPLC method for the simultaneous determination of enalapril maleate in present of their impurities: application to tablet analysis. Int J Appl Pharm 2018;10:98-102.

30. Liliya L, Dmytro K, Olena S, Ihor B, Tamara K. Development of methodology for identification of captopril in medicines. Asian J Pharm 2016;10:168-71.

31. Logoyda L, Korobko D, Saprun S, Zarivna N. Development of methods for the chromatographic identification of active pharmaceutical ingredient from group of angiotensinconverting enzyme inhibitors in pharmaceuticals. Int J Green Pharm 2017;11 Suppl:737-41.

32. Liliya Logoyda, Dmytro Korobko, Iryna Ivanusa, Kovalenko Serhii. Development of the methodology of the chromatographic determination of nifedipine in medicines. Asian J Pharm Clin Res 2017;10:149-52.

33. Logoyda Liliya, Korobko Dmutro, Saprun Stanislav. Development of methods for identification of calcium channel blockers in medicines. Int J Res Ayurveda Pharm 2016;7:88-91.

34. Olgya Polyauk, Liliya Logoyda. The investigation of conditions of API from group of calcium channel blockers extraction by organic solvents by using high-performance liquid chromatography as method assay. Asian J Pharm Clin Res 2017;10:354-6.

35. Kondratova Y, Adebayo T, Logoyda L, Korobko D, Berdey I, Kuchmerovska T. Development of the methodology of the chromatographic determination of amlodipine in medicines. Int J Res Ayurveda Pharm 2016;7:32-5.

36. Logoyda L, Abdel Megied AM, Kondratova Y, Trofimenko O, Korobko D, Dakhym I. Development and validation of HPLC method for the simultaneous determination of enalapril maleate in present of their impurities: application to tablet analysis. Int J Appl Pharm 2018;10:98-102.

37. Liliya Logoyda, Dmytro Korobko, Oleksandra Oleshchuk, Taras Proniv, Mariya Dmutriv. A HPLC MS/MS method development and validation for the simultaneous determination of bisoprolol and enalapril in the present of enalaprilat in human plasma. Int J Appl Pharm 2018;10:31-40.

38. Logoyda L, Mykhalkiv M, Polyauk O, Zarivna N, Soroka Y, Demydiak O. Ultra-high-performance liquid chromatography as assay method for the investigation of conditions of captopril extraction by organic solvents. Asian J Pharm 2018;12 Suppl:111-4.

39. Mykhalkiv M, Logoyda L, Polyauk O, Zarivna N, Soroka Y, Ryabokon S, Riabokon M. HPLC as assay method for the investigation of conditions of bisoprolol extraction by organic solvents. Int J Green Pharm 2018;12 Suppl:276-9.

40. Liliya Logoyda. Bioanalytical method development and validation from the simultaneous determination of verapamil and enalapril in the present of enalaprilat by HPLC MS/MS. Int J Appl Pharm 2018;10:19-27.

41. Liliya Logoyda. Quantitative determination of amlodipine from caco-2 cell monolayers by high-performance liquid chromatography-mass spectrometry/mass spectrometry. Asian J Pharm Clin Res 2018;11:204-7.

42. Yuryeva O, Kondratova Y, Logoyda L. Development of highperformance liquid chromatography method for simultaneous analysis of amlodipine and valsartan in combined dosage form and in vitro disslotution studies. Asian J Pharm Clin Res 2018;11:200-4.

43. Mykhalkiv M, Logoyda L, Ivanusa I, Soroka Y, Yakubishyna I. High-performance liquid chromatography as assay method for the investigation of conditions of enalapril maleate extraction by organic solvents. Int J Green Pharm 2018;12:62-5.

44. Logoyda L, Kondratova Y, Korobko D, Susla O, Soroka Y, Tsytsiura R, Pidruchna S. Youden's test of the chromatographic determination of captopril in pharmaceuticals. Int J Green Pharm 2017;11:188-91.

45. Liliya Logoyda. A HPLC-MS/MS method development and validation for the simultaneous determination of nifedipine and enalapril in human plasma. Int J Appl Pharm 2018;10:35-42.

46. Liliya Logoyda. A high-performance liquid chromatographymass spectrometry method development for the quantitative 
determination of enalapril maleate from caco-2 cell monolayers. Asian J Pharm Clin Res 2018;11:89-92.

47. Logoyda L, Korobko D. A high-performance liquid chromatography-mass spectrometry/mass spectrometry method development for the quantitative determination of bisoprolol from caco-2 cell monolayers. Asian J Pharm Clin Res 2018;11:386-9.

48. SK Dubey, S Kumar, RJ Mudakavi, S Deshpande. Development and validation of UV-spectrophotometric method for determination of Enalapril maleate. Int J Adv Pharm Sci 2010;1:375-80.

49. Ayad MM, Shalaby AA, Abdeellatef HE, Hosny MM. Spectrophotometric and AAS determination of ramipril and enalapril through ternary complex formation. J Pharm Biomed Anal 2002;28:311-21.

50. Baraka MM, El Sadek M, Mousa EM, Abd Alaty NM. Spectrophotometric and atomic absorption determination of ramipril, enalapril maleate and fosinopril through ternary complex formation with molybdenum (V)-thiocyanate (Mo (V)-SCN). Chem Pharm 2008;56:1521-7.

51. Ayad MM, Shalaby A, Abdellatef HE, Hosny MM. Spectrophotometric methods for determination of enalapril and timolol in bulk and in drug formulations. J Pharm Biomed Anal 2002;28:311-21.

52. Stolarczyk M, Maslanka A, Krzek J, Milczarek J. Application of derivative spectrophotometry for determination of enalapril, hydrochlorothiazide and walsartan in complex pharmaceutical preparations. Acta Poloniae Pharm 2008;65:275-81.

53. Sowjanya G. Simultaneous UV spectrophotometric estimation of enalapril maleate and hydrochlorothiazide in tablets. J Chem Pharm Res 2012;4:3483-8.

54. Patil PS, More HN. Difference spectrophotometric estimation of enalapril maleate from tablet dosage form. Int J Res Pharm Biomed Sci 2011;2:629-33.

55. Rahman N, Manirul Haque SK. Optimized and validated spectrophotometric methods for the determination of enalapril maleate in commercial dosage forms. Anal Chem Insights 2008;3:31-43.

56. Gherman S, Zavastin D, Spac A, Dorneanu V. Development and validation of UV spectrophotometric method for determination of enalapril maleate from commercial dosage forms. Farmacia 2015;63:934-7.

57. Manindra M, Zafar HS, Ankur K. Validation of stability indicating HPLC method for the determination of enalapril maleate in tablet formulations. Int J Pharm Pharm Sci 2011;3 Suppl 5:180-3.

58. Al-Momani F. Determination of hydrochlorothiazide and enalapril maleate in tablet formulations by reversed-phase. Turk J Chem 2001;25;49-54.

59. Vidyadhara BV Rao, K Tejaswiand, AL Rani. Analytical method development and validation for simultaneous estimation of enalapril maleate and hydrochlorothiazide by RP-HPLC/S. Der Pharm Chem 2014;6:217-23.

60. Chaudhari BG. Development and validation of Rp-Hplc method for simultaneous stimation of enalapril maleate and amlodipine besylate in combined dosage form. J Appl Pharm Sci 2012;2:54-7.
61. Sultana N, Saeed A, Naveed S. Simultaneous determination of enalapril and statin's in pharmaceutical formulations by Rphplc. J Chilean Chem Soc 2011;56:734-7.

62. Chaitanya Sai B, Satish Kumar V, Satish Babu K, Ravindra Babu SVD. Simultaneous high-performance liquid chromatographic determination of enalapril and felodipine in pharmaceuticaldosage form. J Chem Pharm Res 2012;4:1383-8.

63. Nagarajan G. Development and validation of a RP-HPLC method for simultaneous estimation of enalapril maleate and ramipril in bulk and tablet dosage form. Der Pharm Lett 2013;5:69-76.

64. Walily AM, Belal SF, Heaba EA, Kersh AE. Simultaneous determination of enalapril maleate and hydrochlorothiazide by first-derivative ultraviolet spectrophotometry and highperformance liquid chromatography. J Pharm Biomed Anal 1995;13:851-56.

65. Tajerzadeh H, Hamidi M. A simple HPLC method for quantitation of enalaprilat. J Pharm Biomed Anal 2001;24:675880.

66. Uslu B, Ozden T. HPLC and UPLC methods for the simultaneous determination of enalapril and hydrochlorothiazide in pharmaceutical dosage forms. Chromatographia 2013;76:1487-94.

67. Danafar H, Hamidi M. Liquid chromatography-tandem mass spectrometry (LC-MS) method for the assignment of enalapril and enalaprilat in human plasma. Pharm Biomed Res 2015;1:47-58.

68. Yoon KH, Kim W, Park J, Kim HJ. Quantification of enalapril in human plasma by liquid chromatography-tandem mass spectrometry. Bull Korean Chem Soc 2004;25:878-80.

69. Shioya H, Shimojo M, Kawahara Y. Determination of enalapril and its active metabolite enalaprilat in plasma and urine by gas chromatography/mass spectrometry. Biomed Chromatogr 1992;6:59-62.

70. Lee J. Simultaneous quantitation of enalapril and enalaprilat in human plasma by 96-well solid-phase extraction and liquid chromatography/tandem mass spectrometry. Rapid Commun Mass Spectrom 2003;17:1157-62.

71. Kocijan A, Grahek R, Kocjan D, Kralj LZ. Simultaneous quantitation of enalapril and enalaprilat in human plasma by 96-well solid-phase extraction and liquid chromatography/tandem mass spectrometry. J Chromatogr B 2001;755:229-39.

72. Qi Gu, Dafang Zhong, Xiaoyan Chen, Yingwu Wang. Simultaneous quantitation of enalapril and enalaprilat in human plasma by liquid chromatography/tandem mass spectrometry. J Chromatography B 2005;813:337-42.

73. Bhardwaj SP, Singh S. Study of forced degradation behavior of enalapril maleate by LC and LC-MS and development of a validated stability-indicating assay method. J Pharma Biomed Anal 2008;46:113-20.

74. Niopas I, Daftsios AC, Nikolaidis N. Bioequivalence study of two brands of enalapril tablets after single oral administration to healthy volunteers. Int J Clin Pharmacol Ther 2003;41:226-30.

75. Siddiqui FA, Sher N, Shafi N, Bahadur SS. Simultaneous determination of metformin, captopril, lisinopril, and enalapril, its application to pharmacokinetics. Arabian J Chem 2013;5:324. 